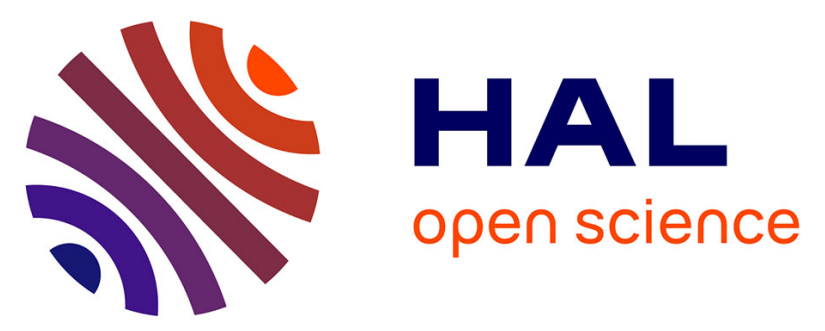

\title{
Characterization of iron and manganese precipitates from an in situ ground water treatment plant.
}

E Mettler, Mustapha Abdelmoula, E. Hoehn, R Schoenenberger, P Weidler, U. von Gunten

\section{- To cite this version:}

E Mettler, Mustapha Abdelmoula, E. Hoehn, R Schoenenberger, P Weidler, et al.. Characterization of iron and manganese precipitates from an in situ ground water treatment plant.. Ground Water Monitoring and Remediation, 2001, 39 (6), pp.921-30. hal-01946075

\section{HAL Id: hal-01946075 \\ https://hal.univ-lorraine.fr/hal-01946075}

Submitted on 5 Dec 2018

HAL is a multi-disciplinary open access archive for the deposit and dissemination of scientific research documents, whether they are published or not. The documents may come from teaching and research institutions in France or abroad, or from public or private research centers.
L'archive ouverte pluridisciplinaire HAL, est destinée au dépôt et à la diffusion de documents scientifiques de niveau recherche, publiés ou non, émanant des établissements d'enseignement et de recherche français ou étrangers, des laboratoires publics ou privés. 


\section{Characterization of Iron and Manganese Precipitates from an in Situ Ground Water Treatment Plant}

S. Mettler ${ }^{1}$, M. Abdelmoula ${ }^{2}$, E. Hoehn ${ }^{1}$, R. Schoenenberger ${ }^{1}$, P. Weidler ${ }^{3}$, U. von Gunten ${ }^{1}$

' Swiss Federal Institute for Environmental Science and Technology (EAWAG), Ueberlandstrasse 133, 8600 Duebendorf, Switzerland

${ }^{2}$ Laboratoire de Chimie Physique pour l'Environnement, 405, rue de Vandoeuvre, 54600 Villers-lès-Nancy, France

${ }^{3}$ Forschungszentrum Karlsruhe GmbH, Division of Nanomineralogy, Section of Water-and Geotechnology, Institute for Technical Chemistry, P.O. Box 3640, D-76021 Karlsruhe

Author to whom all correspondence should be addressęd:

$$
\begin{gathered}
\text { U. von Gunten } \\
\text { Tel: } \quad+4118235270 . \\
\text { Fax: } \quad+4118235210 \\
\text { Email: vongunte@eawag.ch }
\end{gathered}
$$

resubmitted to Ground Water, August 2001 


\section{Abstract}

Aquifer samples from the precipitation zone of an in situ iron and manganese removal plant that was operated for ten years were analyzed for iron and manganese minerals. Measurements were performed by various chemical extraction techniques ( $5 \mathrm{M} \mathrm{HCl}, 0.008 \mathrm{M} \mathrm{Ti}(\mathrm{III})$ EDTA, 0.114 M ascorbic acid), X-ray diffraction and Mössbauer spectroscopy. Chemical extractions showed that iron was precipitated as ferric oxides, whereas manganese was not oxidized but deposited as $\mathrm{Mn}(\mathrm{II})$ probably within carbonates. The ferric oxides in particular accumulate preferentially in the smaller grain size fractions. This tendency was observed to a lesser extent for manganese. X-ray diffraction and Mössbauer spectroscopy showed that the ferric oxides were mainly crystalline (goethite, $50-100 \%$ of the iron). Ferrihydrite was found as well, but only as a minor fraction $(\leq 12 \%)$. Pure manganese minerals were not found by $\mathrm{X}$ ray diffraction. The precipitated amounts of iron ( 5 to $27 \mu \mathrm{mol} / \mathrm{g}$ Fe as ferric oxide) and manganese (I to $4 \mu \mathrm{mol} / \mathrm{g} \mathrm{Mn}$ ) during ten years operation of the treatment plant agree with values that were estimated from operational parameters $(9-31 \mu \mathrm{mol} / \mathrm{g} \mathrm{Fe}$ and $3-6 \mu \mathrm{mol} / \mathrm{g} \mathrm{Mn})$. Considering the small amounts of precipitated iron and manganese, no long term risks of clogging of the aquifer are expected.

\section{Keywords:}

In situ deferrization, demanganation, ground water, iron, manganese, oxidation, chemical extraction, X-ray diffraction, Mössbauer spectroscopy.

\section{Introduction}

The concentrations of iron and manganese in natural waters are controlled by the solubility of the corresponding oxidic phases explaining their low concentrations in most waters. In the ab- 
sence of oxygen, Fe-oxides and Mn-oxides ${ }^{1}$ can function as electron acceptors; mostly biotic processes reduce $\mathrm{Fe}(\mathrm{III})$ and $\mathrm{Mn}(\mathrm{III}, \mathrm{IV})$ to the divalent ions that have a much higher solubility. These processes take place in lakes or in aquifer systems rich in organic matter where oxygen is depleted and a whole series of reduction processes can occur (Cornell and Schwertmann, 1996; Lovley, 1987; Lovley and Phillips, 1988; von Gunten and Zobrist, 1993).

If such reduced ground waters are used for drinking water production, iron and manganese have to be removed before distribution. Even if these metals are of no toxicological concern, iron and manganese have various undesired effects in drinking water: corrosion, precipitation and clogging of pipes, staining of laundry and in some cases a strong metallic taste. Therefore, the World Health Organization (WHO) recommends removal of Fe and Mn when concentrations are higher than $0.3 \mathrm{mg} / \mathrm{L}$ and $0.1 \mathrm{mg} / \mathrm{L}$, respectively (World Health Organization, 1996). Similar standards are adopted in different countries: $0.3 \mathrm{mg} / \mathrm{L}$ and $0.05 \mathrm{mg} / \mathrm{L}$ in the USA (USEPA, 2001), and $0.2 \mathrm{mg} / \mathrm{L}$ and $0.05 \mathrm{mg} / \mathrm{L}$ in the European Union (European Union, 1998).

In general iron and manganese are removed after pumping the ground water by oxidation followed by filtration. The oxidation step is conducted either chemically by various oxidants $\left(\mathrm{Cl}_{2}, \mathrm{ClO}_{2}, \mathrm{KMnO}_{4}, \mathrm{O}_{2}\right)$ or microbiologically, using iron or manganese oxidizing microorganisms (Mouchet, 1992). Frequently, separate treatment steps are needed for chemical or biological deferrization and demanganation because of the different reaction conditions for the oxidation step. This leads to relatively high investment costs. In addition the filtration produces large volumes of $\mathrm{Fe}$ - and $\mathrm{Mn}$-sludge, which have to be disposed.

Alternatively, in situ treatment can be applied. where iron and manganese are precipitated di-

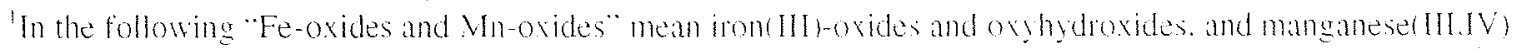
dioxides or oxyhydroxides. respectively.
} 
rectly in the aquifer after oxygenation. For this purpose air-saturated water is injected in the aquifer. Compared to conventional treatment, this requires only a relatively simple infrastructure. Other advantages of in situ removal of iron and manganese are significantly less clogging of the supply well, no sludge disposal and no dosing of chemicals (Groth et al., 1988; Hallberg and Martinell, 1976; Mengis, 1984; Meyerhoff, 1995; Rey and Schindler, 1984). Despite these advantages, in situ treatment is applied with reservation: questions about reaction mechanisms, efficiency and consequences for the aquifer are not entirely resolved. Especially, the risk of clogging by the reaction products raises questions about the lifetime of such installations.

In previous studies of in situ treatment, both chemical and biological oxidation were proposed as removal mechanisms. In the chemical pathway, iron or manganese is oxidized after prior adsorption on natural surfaces (oxides, carbonates). Biological oxidation is mediated by iron or manganese oxidizing microorganisms. In most previous studies, optimum operation conditions were investigated with less emphasis on precipitation products (Appelo et al., 1999; Boochs and Barovic, 1981; Groth et cl., 1988; Hallberg and Martinell, 1976; Kölle and Schneider, 1992; Mengis, 1984; Olthoff, 1986; Rundell and Randtke, 1987; van Beek, 1985; Zienkiewicz, 1984). Usually, the size of the precipitation zone is designed to be large enough to ensure a lifetime of the treatment plant of at least one hundred years. This can be calculated, based on the dry bulk density and the porosity of the aquifer and the expected amount of precipitated iron- and manganese-oxides (Hallberg and Martinell, 1976; Mengis, 1984; Rott and Meyerhoff, 1993). No reports of aquifer clogging under these conditions were found in the literature. In a demonstration plant Olthoff (1986) found "hardly measurable changes of permeability". Jechlinger et al. (1985) could not observe any major precipitates exceeding a few percent of the pore volume. However, in both cases the systems were only operated for a short time (up to two years). In some case aquifer material after in situ treatment was ana- 
lyzed. Oxalate / dithionite extractions showed that half of the ferric oxides were poorly crystallized. Additional X-ray diffraction showed traces of lepidocrocite (Olthoff, 1986). By microscopy, "hot spots" were found where up to $12 \%$ of the pore volume was filled with Feoxides in a 10 years old in situ deferrization plant. These spots were located at the interface of well (sand and gravel) and less permeable layers (Kleefeldt, 1988).

It is generally accepted that for an efficient and long lasting in situ treatment plant the precipitates should be crystalline, which requires a smaller precipitation zone (filter volume) than amorphous, more voluminous products (Braester and Martinell, 1988; Olthoff, 1986; Seyfried and Olthoff, 1985). It has been shown that, for the type of products formed by oxidation of Fe(II) and subsequent precipitation of ferric oxides, reaction conditions have a high impact on product formation (Cornell and Schwertmann, 1996).

In the present study we will focus on the precipitates formed in an in situ removal plant in La Neuveville (Switzerland). The following main questions were addressed:

- Can iron or manganese phases, produced by in situ treatment, be identified?

- What kind of minerals are precipitated?

- Are there preferential precipitation zones, sites or surfaces?

- Based on these findings, what is the risk of clogging the aquifer?

\section{La Neuveville site}

The site of La Neuveville is located in western Switzerland. At this site an alluvial deltaic aquifer lies over limestone till (Rey and Schindler, 1984). The sediment material of the aquifer is highly heterogeneous, and the water table is at a depth of ca. $2 \mathrm{~m}$. At a depth of $18-19 \mathrm{~m}$. an impermeable layer of clay forms the bottom of the aquifer.

Ground water contains dissolved iron and manganese in concentrations of 0.3 to $1 \mathrm{mg} / \mathrm{L}$ and $0.1-0.2 \mathrm{mg} / \mathrm{L}$ respectively: the dissolved oxygen concentration is below $1 \mathrm{mg} / \mathrm{L}$. The $\mathrm{pH}$ of the ground water varies between 7.0-7.3 and the temperiture between 10 and $1.3^{\circ} \mathrm{C}$. it has a 
hardness of $25^{\circ} \mathrm{fH}\left(250 \mathrm{mg} / \mathrm{L} \mathrm{CaCO}_{3}\right)$. The ground water contains $\mathrm{NO}_{2}^{-}(5 \mu \mathrm{g} / \mathrm{L}), \mathrm{NO}_{3}^{-}(0.5$ $\mathrm{mg} / \mathrm{L}), \mathrm{NH}_{4}^{+}(0.8 \mathrm{mg} / \mathrm{L}), \mathrm{Cl}^{-}(10 \mathrm{mg} / \mathrm{L})$, the DOC concentration is $1.5 \mathrm{mg} / \mathrm{L}$ and the conductivity is around $400 \mu \mathrm{S}$.

An in situ plant for iron and manganese removal from ground water, which is depicted in figure 1, was installed in La Neuveville in 1988. Ground water is pumped through two screened parts of a water supply well at depths of $4.8-6.8 \mathrm{~m}$ and $8.6-18.6 \mathrm{~m}$ with a pumping flow rate of $2400 \mathrm{~L} / \mathrm{min}$. At a distance of $7 \mathrm{~m}$ from the supply well, there are five injection wells (satellites), where air-saturated water is injected intermittently to regenerate the oxidation zone (oxygen $=8 \mathrm{mg} / \mathrm{L}$; iron and manganese $<0.2 \mathrm{mg} / \mathrm{L}$ ). Injection periods last for about one day (injection flow rate $480 \mathrm{~L} / \mathrm{min}$ ). To ensure a complete removal of iron and manganese the treatment plant is designed to have overlapping oxidation zones around the satellites. The precipitation zone comprises the entire volume of inflowing water. After the injection period iron and manganese free water can be pumped from the supply well until concentrations of the metal rise above drinking water standards (ca. 5-10 days). A continuous supply of drinking water is only possible because the site is operated with two identical well systems, which are alternatively exploited and regenerated.

\section{Materials and Methods}

All solutions were made with deionized water ( $\mathrm{Q}-\mathrm{H}_{2} \mathrm{O}$ grade Barnstead nanopure). Chemicals were at least reagent grade (Fluka or Merck): Titanium chloride $15 \%$ in $\mathrm{HCl}$ and Ferrozine, Hydrochloric acid (32\%), L-ascorbic acid. Ethylene-diamine-tetra-acetic acid disodium salt, $\mathrm{MnO}_{2}$ (pyrolusite) and acetic acid.

Aquifer sample selection

All samples in this study were taken from a new bore hole $(18.8 \mathrm{~m}$ deep) drilled in the precipitation zone between two injection wells (Fig. 1). Samples from the depths of $4-5 \mathrm{~m}, 7.5-8$ $\mathrm{m}, 11.3-11.8 \mathrm{~m}, 12.5-13 \mathrm{~m}$ and 17-17.5 $\mathrm{m}$ were analyzed. The sample from $4-5 \mathrm{~m}$ represents a 
reference above the precipitation zone, similar to the aquifer before the installation of the treatment plant. To normalize the concentrations to reproducible quantities of aquifer material, measurements were partly performed with sieved samples. The samples were dried for 1 hour at $100^{\circ} \mathrm{C}$ and then sieved dry with metallic sieves to separate the fractions of different grain size. This treatment does not transform amorphous Fe-oxides into more crystalline forms (Weidler, 1997). The grain size fractions $<0.063 \mathrm{~mm}, 0.063-0.09 \mathrm{~mm}, 0.09-0.125 \mathrm{~mm}$, $0.125-0.25 \mathrm{~mm}$ and $0.25-0.5 \mathrm{~mm}$ were investigated; they represent a large fraction of the specific surface area and are expected to be coated with fresh precipitates. Four other samples were analyzed without sieving: these are the stones P1 and P20, found at 16.1 and $17.1 \mathrm{~m}$, as well as samples $\mathrm{P} 22$ and $\mathrm{P} 24$, consisting of gravelly material from the depths $6.4 \mathrm{~m}$ and 9.0 m. P1 is a calcite stone with a diameter of about $15 \mathrm{~cm}$, coated with an orange-brown layer. P20 consists of several orange-brown stones (diameter ca. $3-5 \mathrm{~cm}$ ), mostly agglomerated sand of quartz and calcite. P1 and P20 were first air dried, then material was scratched from the surface of the colored spots and ground with an agate mortar for measurements. Samples P22 and P24 were frozen under argon atmosphere and then freeze dried, with only the most colored material chosen for analysis.

\section{Analytical methods}

Metals were measured with flame atomic absorption spectroscopy (Perkin Elmer 5100 PC): Detection limits for Fe and $\mathrm{Mn}$ were $0.03 \mathrm{mg} / \mathrm{L}$ and $0.01 \mathrm{mg} / \mathrm{L}$, respectively. Ferrous iron (FeII) was measured separately with the Ferrozine method with a detection limit of approximately $3 \times 10^{-7} \mathrm{M}$ in a $1 \mathrm{~cm}$ cuvette (Gibbs, 1976: Stookey, 1970).

\section{Chemical characterization of $\mathrm{Fe}$ - and $\mathrm{Mn}$ oxides}

The following dissolution methods were used to characterize the iron and manganese minerals in the aquifer: acid dissolution with $5 \mathrm{M}$ hydrochloric acid, reductive dissolution with ascorbic acid $(0.114 \mathrm{M})$ at $\mathrm{pH} 8$ and an EDTA complex of titanium $111(0.008 \mathrm{M})$ at $\mathrm{pH} 7$ 
(TiEDTA). The methods were described and applied previously (Amirbahman et al., 1998; Heron et al., 1994; Kostka and Luther III, 1994). Reductive dissolution methods are widely used to characterize Fe-oxides; in the present study we used the same methods for the identification of Mn minerals. However, for the latter, additional test experiments on synthetic Mnoxides had to be performed (see below). Because of the metal binding character of the buffers used in reductive extractions, dissolution experiments were also conducted without a reducing agent to correct the results for this blank. All of the concentrations given below are mean values of three measurements, the indicated error is the standard deviation of these measurements.

For all dissolution experiments, aliquots of a sample $(0.2-1 \mathrm{~g})$ were equilibrated with the reagents for 24 hours, and suspensions were filtered through $0.45 \mu \mathrm{m}$ filters (Sartorius, cellulose nitrate) and analyzed for the metal concentrations.

In the present study dissolution in $5 \mathrm{M} \mathrm{HCl}$ is defined as yielding total manganese $\left(\mathrm{Mn}_{\text {tot }}\right)$ and iron $\left(\mathrm{Fe}_{\mathrm{tot}}\right)$ contents of the aquifer material. TiEDTA extraction has been shown to dissolve most of the Fe- oxides except magnetite. Therefore, it corresponds to the total content of ferric oxides (FeIII(TiEDTA)). Ascorbic acid only dissolves the amorphous fraction of Fe-oxide (FeIII(AscA)). Thus the difference between the dissolved iron from TiEDTA and ascorbic acid yields the crystalline ferric oxides.

Additional test experiments on Mn-oxides dissolution allow the following conclusion: $5 \mathrm{M}$ $\mathrm{HCl}$ treatment dissolves $\mathrm{MnO}_{2}$ almost entirely (>87\%). Reductive methods were not as selective for crystalline (pyrolusite. Merck) and synthesized amorphous manganese dioxide (Murray. 1974) as for the Fe-oxides. The reduction by ascorbic acid dissolved both the crystalline and the amorphous $\mathrm{MnO}_{2}$. However, the citrate buffer already completely dissolved the amorphous $\mathrm{MnO}_{2}$. It dissolves Mn(It)-containing carbonates as well, and thus does not differentiate between $\mathrm{Mn}(\mathrm{II})$ and $\mathrm{Mn}$ (III. IV roxides. TiEDTA reduced all the amorphous and half of 
the crystalline $\mathrm{MnO}_{2}$. Therefore, the TiEDTA method is more specific for Mn- oxides than the other treatment and is used here to quantify the fraction of Mn-oxides.

\section{Concentration of aquifer samples}

$X$-ray diffraction (XRD) measurements showed a high content of calcite in the aquifer material $(\geq 30 \%)$. To concentrate the samples with respect to Fe- and Mn-oxides, the calcite was selectively removed by shaking $1 \mathrm{~g}$ of the sample in $10 \mathrm{ml}$ of a $20 \%(\mathrm{v} / \mathrm{v})$ solution of acetic acid during 24 hours (Mahapatra et al., 1996). The resulting suspensions were then centrifuged for 10 minutes at $8000 \mathrm{rpm}$ and finally stabilized by freezing; for spectroscopic measurements they were freeze dried. The method was tested on synthetic ferrihydrite (prepared according to Schwertmann and Cornell, 1991) as well as with amorphous and crystalline manganese dioxide (same materials as above). Only the amorphous manganese dioxide was dissolved entirely. The other synthetic oxides were not affected by this treatment. To check the influence of the acetic acid pretreatment on chemical extractions, they were repeated after acetic acid pretreatment. For the chemical extraction methods, the resulting concentrations were the same for treated and untreated samples, because the analyzed iron or manganese fractions were always related to the initial dry weight of the sample before calcite was removed. Spectroscopic results, however, refer to the remaining sample mass free of calcite.

\section{X-ray Diffraction (XRD)}

$X$-ray diffraction allows the determination of crystalline minerals in natural samples as long their concentration is larger than a few percent (w/w). XRD-measurements were performed with samples from the smallest grain size fraction of the sieved samples $(<0.063 \mathrm{~mm})$ and with specially collected samples P1, P20, P22, P24, which were hand ground in an agate mortar with ethanol (with acetone in the case of samples treated with acetic acid). The XRD measurements were performed on a Scintag XDS 2000. (Bragg-Brentano geometry) with a CuKa X-ray radiation wavelength $(\lambda=0.15+18 \mathrm{~nm})$ and a solid state lithium-silicium detec- 
tor. Some measurements were performed in continuous scan mode $(0.5$ and $1 \%$ minute $)$ over a $2 \Theta$ range of $2-70^{\circ}$. The samples which were quantified by Rietveld refinement as well as the sediments pretreated in dilute acetic acid were measured in the step scan mode between $10^{\circ}<$ $2 \Theta<70^{\circ}$ with an interval of $0.025 \% 4$ seconds. The diffractograms were interpreted by Rietveld refinement using the multiphase Rietveld package WYRIET (Schneider, 1989; Schneider and Dinnebier, 1991). This is a least square fit of variables combining a crystallographic database, the optics of the apparatus and the peak shape (Weidler et al., 1998).

\section{Mössbauer spectroscopy}

${ }^{57} \mathrm{Fe}$ Mössbauer spectroscopy is the most proficient method to characterize the iron species in solid phases. Mössbauer spectra can reveal the presence of minute amounts of Fe- oxides associated with phyllosilicates, but moreover, they enable an unequivocal identification of these minerals and their quantification down to $1 \% \mathrm{w} / \mathrm{w}$ ratio of mineral to total sediment mass (Murad and Wagner, 1994). The Mössbauer spectra were measured by means of a constant acceleration spectrometer with a $50 \mathrm{mCi}$ source of ${ }^{57} \mathrm{Co}$ in $\mathrm{Rh}$. The spectrometer was calibrated with a $25 \mu \mathrm{m}$ foil of $\alpha$-Fe at room temperature. The products were analyzed at low temperature $(12 \mathrm{~K})$ to distinguish goethite, ferrihydrite and phyllosilicates. The cryostat consisted of a closed Mössbauer cryogenic workstation with a vibration insulation stand manufactured by Cryo Industries of America ${ }^{\text {. }}$. Computer fittings were done using Lorentzianshape lines with variable widths for taking into account spectral asymmetry.

\section{Results and Discussion}

\section{Grain size distribution of the aquifer material}

The grain size distribution of the sieved samples is shown in Fig. 2. Two types of aquifer material can be distinguished: a sand type and a gravel type. The samples from a depth of $7.5-$ $8.0 \mathrm{~m}$ and $11.3-11.8 \mathrm{~m}$ containing around $10 \%$ of clay and sitt (fraction $<0.063 \mathrm{~mm}$ ) as well as 
50 to $70 \%$ sand (fraction $0.063-2 \mathrm{~mm}$ ) are referred to as sand type. Samples from a depth of 4.0-5.0 m, 12.5-13.0 $\mathrm{m}$ and 17.0-17.5 m consist merely of gravelly material (fraction $>2 \mathrm{~mm}$ is larger than $50 \%$ ).

\section{Extraction by $5 \mathrm{M} \mathrm{HCl}\left(\mathrm{Fe}_{\mathrm{tot}}, \mathrm{Fe}(\mathrm{II}), \mathrm{Mn}_{\mathrm{tot}}\right)$}

(i) Iron

The results from the acid extractions are shown in Fig. 3. Figure 3a shows the concentration of $\mathrm{Fe}_{\mathrm{tot}}$ for each grain size fraction at various depths. $\mathrm{Fe}_{\mathrm{tot}}$ is significantly higher in all four samples situated below the reference sample. The specific $\mathrm{Fe}_{\mathrm{tot}}$ content increases with decreasing grain size and is usually twice as high in the smallest grain size compared to the largest. This difference in $\mathrm{Fe}_{\mathrm{tot}}$ distribution among the grain size fractions is not seen in the reference sample ( $4-5 \mathrm{~m}$ ), which indicates that the deeper samples have been altered by the in situ deferrization.

\section{(ii) Manganese}

The same representation is shown for $\mathrm{Mn}_{\mathrm{tot}}$ in Fig. 4. In a similar way there is more $\mathrm{Mn}_{\mathrm{tot}}$ in the samples from the precipitation zone $(>5 \mathrm{~m}, 4-9 \mu \mathrm{mol} / \mathrm{g})$ than in the reference sample (4-5 $\mathrm{m}, 3$ to $4 \mu \mathrm{mol} / \mathrm{g}$ ). In the sample from a depth of $4-5 \mathrm{~m}$ there is almost no grain size dependence, whereas the other samples show a higher content in the smaller grain sizes, but not as pronounced as for $\mathrm{Fe}_{\mathrm{i} H}$.

\section{Reductive dissolution experiments}

(i) Iron:

The total Fe- oxide concentrations (FeIII(TiEDTA)) determined by the TiEDTA extraction are shown in Fig. 3b. A comparison with Fig. 3a shows that ferric oxides account for the major fraction of iron ( $50-80 \%$ of $\left.\mathrm{Fe}_{\mathrm{lw}}\right)$ in the analyzed grain size fractions. There is again significantly more FeIII(TiEDTA) in the deeper samples than in the reference sample (4.0-5.0 
m). The distribution of the ferric oxides is strongly grain size dependent. The largest difference between the background sample and the other samples is observed for the smallest grain size fractions, whereas in the $0.25-0.5 \mathrm{~mm}$ fraction, the Fe(III)-oxide contents are similar in the sample from 4-5 $\mathrm{m}$ and in the lower samples (30-35 $\mu \mathrm{mol} / \mathrm{g})$. Amorphous ferric oxides, determined by dissolution with ascorbic acid FeIII(AscA), make up a very small fraction of the ferric oxides, slightly higher in the reference sample (8-12\%) than in the deeper samples $(<6 \%)$ (data not shown).

Figure $3 \mathrm{c}$ shows the concentration distribution of the difference between $\mathrm{Fe}_{\mathrm{tot}}$ and FeIII(TiEDTA). No large difference is found for the various grain size fractions, demonstrating that the pattern of $\mathrm{Fe}_{\mathrm{tot}}$ dependence on the grain size in the samples below $5 \mathrm{~m}$ is due to the ferric oxides. This is an evidence that most of the FeIII(TiEDTA) fraction is produced by the in situ treatment. Ferrous iron, which was measured from the $5 \mathrm{M} \mathrm{HCl} \mathrm{extract,} \mathrm{does} \mathrm{not}$ account entirely for the non-reducible Fe fraction, additional forms of iron are present which are not reducible by TiEDTA. The striking pattern of the FeIII(TiEDTA) distribution among grain sizes suggests that precipitation of Fe-oxides is related to the available surface area. The specific surface area (SSA, $\mathrm{m}^{2} / \mathrm{g}$ ) is larger for small particles and can be calculated from their radius and the density of the aquifer sediment $\left(2.6 \mathrm{~g} / \mathrm{cm}^{3}\right)$. In Fig. 5 FeIII(TiEDTA) concentrations are plotted versus the calculated specific surface area and show a good linear correlation. The straight line for the samples below the reference sample $(<5 \mathrm{~m})$ have a higher slope than the straight line for the reference. The origin is about the same for all samples including the reference and amounts to $21-28 \mu \mathrm{mol} / \mathrm{g}$.

In addition to the sieved samples, the stones P1 and P20 as well as the samples P22 and P24 were measured for $\mathrm{Fe}_{\mathrm{t},}$, Felli(TiEDTA) and FeIII(AscA). The samples PI and P20 are enriched in ferric oxides: they contain at least ten times more than the sieved samples. For P22 and P24, the Fe-concentrations are similar to the concentrations in the sieved samples. but the 
ferric oxide fraction is more important, $90-100 \%$ of the iron dissolved by $5 \mathrm{M} \mathrm{HCl}$ is reducible by TiEDTA. In samples P1, P20, P22 and P24, the Fe-oxides are crystalline to an extent of over $95 \%$.

\section{(ii) Manganese:}

In the sieved samples reductive reagents extracted only small amounts of manganese, inferring that most of the manganese ( $\mathrm{Mn}_{\mathrm{to}}$, Fig. 4 ) is present as $\mathrm{Mn}(\mathrm{II})$. The samples $\mathrm{P} 1, \mathrm{P} 20, \mathrm{P} 22$ and P24 contained two to three times more $\mathrm{Mn}_{\text {tot }}$ than the sieved samples and $\mathrm{Mn}$ was mostly reducible by TiEDTA (60 to $80 \%$ of $\mathrm{Mn}_{10 t}$ ). These are the only samples containing significant Mn-oxide concentrations, which occur together with the largest crystalline Fe-oxide fraction. The oxygenation of manganese(II) is much slower than the oxygenation of iron(II) (Stumm and Morgan, 1996). At pH 7 and in the absence of microorganisms the oxygenation of Mn(II) has a half-life time of in the order of years (Diem and Stumm, 1984), and ferric oxides are known to enhance its oxidation (Davies and Morgan, 1989). Therefore, the association of Mnoxides with Fe-oxides is not surprising and suggests a Fe-oxide catalyzed mechanism. Additional information can be gained from sieved samples by comparing extraction results for the Mn fractions, $\mathrm{Mn}_{\text {tot }}$ and $\mathrm{Mn}(\mathrm{III}, \mathrm{IV})(\mathrm{TiEDTA})$, with and without pretreatment with acetic acid (for selective calcite removal), in Table 1. No significant manganese concentrations were found by reductive dissolution (Mn(III,IV)(TiEDTA). At least $50 \%$ of the total manganese of the sieved samples is soluble in acetic acid solutions (HAc). Thus it is likely that the mostly bivalent manganese is incorporated in the calcite matrix or even present as manganous carbonate (rhodocrosite). Solubility calculations indicate that the system is saturated with respect to $\mathrm{MnCO}_{3}\left(\mathrm{~K}_{* \mathrm{i}}=2.5 \times 10^{-11}, \mathrm{I}=0.02, \mathrm{~T}=15^{\circ} \mathrm{C}\right)$ under the chemical conditions found in the ground water of La Neuveville with a hardness of $5 \mathrm{mM} \mathrm{HCO}_{3}$, a pH of 7.2 and $0.2 \mathrm{mg} / \mathrm{L} \mathrm{Mn}(\mathrm{II})$. These ground water parameters indicate a $\mathrm{CO}$, partial pressure, which is 50 times higher than the atmospheric partial pressure. The air-saturated ground water, which 
is injected back into the aquifer, has lost its excess of carbon dioxide, which leads to a higher $\mathrm{pH}$ (calculated $\mathrm{pH} 8.8$ ). Therefore it will be oversaturated with respect to the carbonate minerals $\mathrm{CaCO}_{3}, \mathrm{MnCO}_{3}$ and $\mathrm{FeCO}_{3}$. Hence, from a thermodynamic point of view, rhodocrosite is likely to precipitate. Only in sample $\mathrm{P} 20$, the amount of $\mathrm{Mn}_{\mathrm{tot}}$ remaining after pretreatment with acetic acid is equivalent to the reducible fraction (Mn(TiEDTA)), indicating the presence of crystalline Mn- oxides (Table 1).

\section{Identification of $\mathrm{Fe}$ - oxides by XRD}

The sieved samples studied by chemical extraction methods (above) as well as samples P1, P20, P22 and P24 were analyzed by XRD. The sieved samples as well as P22 and P24 did not show reliable signals of any iron or manganese containing minerals. The iron and manganese content of these samples was below the detection limit of this method $(1-2 \%$, w/w FeOOH, resp. $\mathrm{MnO}_{2}$ ). However, samples $\mathrm{P} 1$ and $\mathrm{P} 20$, which were found in the same bore core and contained brown-orange coatings, showed significant amounts of goethite. Also, in these samples, no manganese minerals could be detected by XRD. By selectively removing calcite with acetic acid we could concentrate the iron fraction of the samples. The aquifer samples P1, P20, P22 and P24 as well as the three sieved samples from a depth of 4.0-4.5 $\mathrm{m}, 11.3-11.8$ $\mathrm{m}$ and $17.0-17.5 \mathrm{~m}$ corresponding to the smallest size fraction $(<0.063 \mathrm{~mm})$ were pretreated with acetic acid and then measured by XRD.

To check the influence of the acetic acid treatment on the Fe-oxides. chemical extractions were repeated after this pretreatment. The corresponding results are shown in Table 2 . The results for $F e_{t w}$ and FeIII(TiEDTA) before $(\varnothing)$ and after pretreatment (HAc) agree within $20 \%$ for almost all of the samples. The largest differences were observed for sample P20 with respect to the fraction Fe, Felli(TiEDTA) and FellI(AscA). This may be due to the inhomogeneity of the samples taken from the surface of the stone. Among the sieved samples the 
largest differences relate to the fractions FeIII(AscA) and Fe(II). For FeIII(AscA), the difference can be related to the small absolute concentrations of this fraction which result in a large relative error. $\mathrm{Fe}$ (II) is partly incorporated in the calcite matrix which is dissolved by acetic acid explaining why there is less $\mathrm{Fe}_{\mathrm{tot}}$ in the pretreated than in the untreated samples.

Figure 6 shows diffractograms of sample P22 with (lower) and without (upper) pretreatment with acetic acid. After pretreatment, calcite disappeared and dolomite remained. The dominant peaks of goethite located at $2 \Theta$ equal to $21.2^{\circ}>36.6^{\circ}>33.2^{\circ}>53.2^{\circ}>34.7^{\circ}>59.0^{\circ}$ (decreasing intensities) become stronger as indicated by the assignments in the lower diffractogram. The presence of goethite becomes evident by the appearance of the peaks at $21.2^{\circ}$ and $53.2^{\circ}$. The diffractograms were quantified by the Rietveld refinement method. The results for samples P1 and P20 without $(\varnothing)$ and with acetic acid pretreatment (HAc) are shown in Table 3. For the other samples goethite concentrations were too low to be detected and Rietveld refinements were performed with the pretreated samples only. The goethite concentration for the initial samples (without pretreatment) was then calculated by multiplication with a concentration factor (numbers with * in Table 3 ). This factor was derived from the calcite content, which was determined by XRD (P1 and P20) or by analyzing the calcium concentrations in the acetic acid extract.

The fraction of calcite in the samples $\mathrm{P} 1$ and $\mathrm{P} 20$ was between 30 and $70 \%(\mathrm{w} / \mathrm{w})$, respectively. Thus a concentration factor of 4 and 1.6 is expected compared to the untreated sample. The Rietveld refinement method indicated $18 \%$ and $36 \%(\mathrm{w} / \mathrm{w})$ of goethite in the untreated samples P1 and P20, respectively. After pretreatment, goethite concentration amounts to 80 and $75 \%$, respectively, corresponding to the expected concentrations for P1 (factor of 4 ) and P20 (factor of 2). In the pretreated samples P22. and P24, the goethite amounts to approximately $5 \%$. With a calcite content of $50 \%$ in both samples, this yields an estimate of $2-3 \%$ goethite in the initial samples. The fraction of goethite in the sieved samples $(<0.063 \mathrm{~mm})$ 
from depths $11.3-11.8 \mathrm{~m}$ and $17.0-17.5 \mathrm{~m}$ is very low, and was determined to be a few percent in the pretreated samples. Because other minerals (not identified) are present in larger amounts in these samples, results from Rietveld refinement are rather qualitative. Their calcite content is $35 \%$ (sample 11.3-11.8 m.) and 40\% (17.0-17.5 m). Thus, the initial samples contain around $1 \%$ goethite. The analyzed material of the sieved samples is less concentrated than P22 and P24, which were selected based on their color.

\section{Mössbauer Spectroscopy}

Mössbauer spectroscopy was applied to further characterize the Fe- oxide fractions in the samples. The results are given in Table 4 as fractions of the iron species relative to the total iron in the sample (in percent). Removing calcite should not affect the relative concentration, but improves the quality of the background. The samples with higher concentrations of iron, P1 and P20, were measured without pretreatment $(\varnothing)$, whereas the others were pretreated with acetic acid (HAc). The sample $17-17.5 \mathrm{~m}(<0.063 \mathrm{~mm})$ was measured before $(\varnothing)$ and after acetic acid pretreatment (HAc). The results for both measurements agree within a few percent, which confirms the observation that the pretreatment does not affect the iron minerals in the samples.

The Fe-oxides goethite and ferrihydrite were identified. In addition, there were other Fe(II) and Fe(III) species. The Mössbauer data of these species correspond to iron in phyllosilicates (isomer shifts of $1.2-1.31 \mathrm{~mm} / \mathrm{s}$ for $\mathrm{Fe}$ (II) and $0.48-0.52 \mathrm{~mm} / \mathrm{s}$ for $\mathrm{Fe}($ III) and quadrupole splitting of $2.81-2.84 \mathrm{~mm} / \mathrm{s}$ and $0.54-0.6 \mathrm{~mm} / \mathrm{s}$. respectively). Goethite is the most abundant iron phase in all the samples, accounting for 40 to $100 \%$ of the total iron. The highest fraction of goethite is found at the surface of the stones PI and P20, accounting for 100 and $84 \%$ of the total iron, respectively. The unsieved samples P22 and P24, follow with 72 and $62 \%$ goethite. This is 150 to $200 \%$ of the goethite fraction found in the sieved samples $(40-50 \%$ of the iron fraction). In all samples ferrihydrite represented only a minor fraction of $\leq 8 \%$ of the 
total iron.

\section{Comparison of the results from the different analytical methods}

Generally a fairly good agreement betwein the different methods can be observed. Table 5 shows a comparison of the results from chemical extraction and XRD. The fraction FeIII(AscA) being negligible, the concentrations of FeIII(TiEDTA) were transformed from $\mu \mathrm{mol} / \mathrm{g} \mathrm{Fe}$ to weight percent $\mathrm{FeOOH}$ using the molecular weight of $\mathrm{FeOOH}$, which allows a comparison with the goethite concentrations from XRD. Similar results for samples P1 with concentrations of goethite between 16 and $18 \%$ were observed with chemical extractions and XRD, respectively. In sample P20, chemical extractions found only half the content measured by XRD, a result possibly due to inhomogeneous sampling. For the samples P22 and P24 the chemical extraction yielded $1 \%$, whereas XRD indicated $3 \%$ goethite. For the sieved samples from a depth of 11.3-11.8 and 17.0-17.5 m chemical extractions resulted in about $1 \%$ goethite, the same as was measured by XRD.

The relative concentrations of $\mathrm{Fe}$-species calculated from the extraction results agree well with the results from Mössbauer spectroscopy in Table 4:50 to 80\% of Fe is found by chemical extraction to be ferric oxides (FeIII(TiEDTA)), compared to Mössbauer indicating 50 to $100 \%$; the amorphous fraction (FeIII(AscA)) makes up $\leq 9 \%$ of the iron (Mössbauer $\leq 8 \%$ ). Among the sieved samples it was found by chemical extraction that the reference sample contains slightly more FeIII(AscA) than the lower samples. This could not be verified with Mössbauer śpectroscopy.

Accumulation of iron and manganese in the aquifer After 10 years, 9 to $31 \mu \mathrm{mol} / \mathrm{g}$ of iron and 3 to $6 \mu \mathrm{mol} / \mathrm{g}$ for manganese are expected in the precipitation zone. These concentrations are based on an estimate for the last 10 years of operation of the treatment plant and are shown in Table 6 . The estimates were calculated from the operational parameters of the plant assuming a homogeneous precipitation of the metals in 
a cylindrical precipitation zone defined by the injection wells (radius $7 \mathrm{~m}$, depth $15 \mathrm{~m}$; see

Fig. 1). The estimate was made with a range of iron and manganese concentrations in the ground water, since these varied over time.

The estimates can now be compared with the measured concentrations from the chemical dissolution of the sieved samples: iron was mostly precipitated as Fe-oxide, and thus FeIII(TiEDTA) is used, whereas for manganese $\mathrm{Mn}_{\mathrm{tot}}$ is used. From these, net or "accumulated" concentrations are calculated, which are the differences between concentrations of the lower samples and the reference sample for each grain size (i.e. correction for the background iron and manganese). The "accumulated" concentrations are then multiplied by the fraction of the corresponding grain size (see grain size distribution, Fig. 2) and summed. The results are shown in Table 7 and represent accumulated Fe-oxide and manganese concentrations for the sample fraction $<0.5 \mathrm{~mm}$; these can be considered as minimum accumulated concentrations. For the other fractions $>0.5 \mathrm{~mm}$ of the samples, it can be assumed from the results (Figs 3 and 4) that they contain less, or at most equal, iron and manganese. Thus the maximum precipitated concentrations will be twice to five times these values, since the fraction $<0.5 \mathrm{~mm}$ makes up 18 to $50 \%$ of the sample. Our calculations yield a minimum range of 5 to $9 \mu \mathrm{mol} / \mathrm{g}$ and a maximum range of 11 to $27 \mu \mathrm{mol} / \mathrm{g}$ (Table 7 ). These numbers can be compared to the estimated 9 to $31 \mu \mathrm{mol} / \mathrm{g}$. For manganese, a minimum of $1 \mu \mathrm{mol} / \mathrm{g}\left(\mathrm{Mn}_{\mathrm{tu}}\right)$ and a maximum of 2 to $4 \mu \mathrm{mol} / \mathrm{g}$ were found, which can be compared to the estimated $3-6 \mu \mathrm{mol} / \mathrm{g}$ manganese. The comparison of the calculated (Table 6 ) and measured (Table 7) concentrations shows good agreement.

The maximum concentrations shown in Table 7 indicate up to more than twice the iron and manganese in the two lower (12.5 $\mathrm{m}$ and $17 \mathrm{~m}$ deep) than in the upper samples $(7.5 \mathrm{~m}$ and $11.3 \mathrm{~m}$ ). This trend can also be seen in Figs. 3 and 4 and these observations can be related to the hydraulic conductivities of the samples. The two lower samples, which were characterized 
based on their grain size distribution as gravel type, allow a larger flow rate than the upper sandy samples (see grain size distribution and Fig. 2).

Most of the goethite was found in samples with very high calcite or mixed calcite and dolomite content: P1 contains $70 \%$ calcite, P20, 36\% calcite and 33\% dolomite. The question is whether these carbonate minerals favor Fe-oxide precipitation and the formation of goethite. Ongoing laboratory studies about adsorption and heterogeneous oxidation on calcite will help to develop an understanding of the formation of these coatings.

\section{Risk of clogging}

The dimensions of the treatment plant were calculated to be large enough to remove the iron and manganese from the ground water. It is assumed that iron is precipitated as crystalline Feoxide (like goethite) and an adequate volume for the precipitation is foreseen. This approach was verified in the present study, with good agreement between measured and expected iron concentrations. Also Fe-oxides were mainly found to be goethite. Manganese could not be identified as Mn-oxide or another predominant mineral (e.g. $\mathrm{MnCO}_{3}$ ). Thus it is more difficult to estimate a volume of precipitated manganese, but at least its amount can be estimated. The solubility of carbonates can be affected through $\mathrm{pH}$ variations caused by the aeration of the ground water.

From this study the highest amount of precipitated iron and manganese is expected on the smallest particles of a coarse aquifer layer.

\section{Conclusions}

The study of aquifer samples from the in situ deferrization and demanganization plant in La Neuveville allows the following conclusions:

- There is a net increase of solid iron and manganese in the precipitation zone. For a 10 years operation time of the plant, the increase of the metals doubles the background con- 
centration of the aquifer. In some hot spots associated with carbonate minerals, a high enrichment in Fe- and Mn-oxides was found.

- The iron was mainly deposited as ferric oxide with a large crystalline fraction, which consists of 50-100\% of goethite. This was confirmed by XRD and Mössbauer spectroscopy.

- Manganese was found essentially as $\mathrm{Mn}(\mathrm{II})$, probably in association with calcite or as $\mathrm{MnCO}_{3}$. Exceptions are the samples with the highest Fe-oxide content (P1, P20), where Mn-oxides were found by chemical extraction.

- Chemical extraction, XRD and Mössbauer yielded similar concentrations of Fe- oxides. This shows that chemical extraction methods are useful tools for the characterization of small contents of Fe- and Mn-oxides.

- The largest accumulations of Fe and Mn are found in the samples of coarser material, which permit a better flow rate. In the same sample the smallest grain size fractions were always more concentrated, with ferric oxides essentially retained in the small fractions (< $0.09 \mathrm{~mm})$

- The amount of precipitation calculated from the treatment plant parameters (dimensions, pumping rate, iron and manganese concentration) and the measured concentrations (chemical extraction) in the precipitation zone are of the same order of magnitude. Therefore, this calculation is a useful tool to dimension the precipitation zone.

If the heterogeneity of the aquifer in La Neuveville is taken into account, the spots highly concentrated in iron or manganese are far smaller than the volume of some impermeable layers.

\section{Acknowledgements}

We thank the Swiss Commission for Technology and Innovation for financial support (grant Nr. 3443.2) and Gebr. Mengis AG for financial and technical support. Arnold Stahel kindly provided the XRD facilities. Jüreg Zobrist and J.-M. Génin are acknowledged for fruilful dis- 
cussions and Gary Amy for revision of the English of the manuscript. Elisabeth Salhi is thanked for assistance in the laboratory and in the field. 


\section{References}

Ami bahman A., R. Schoenenberger, A. Johnson, and L. Sigg. 1998. Aqueous- and solidphase biogeochemistry of a calcareous aquifer system downgradient from a municipal solid waste landfill (Winterthur, Switzerland). Environmental Science and Technology 32: $1933-1940$.

Appelo C. A. J., B. Drijver, R. Hekkenberg, and M. D. Jonge. 1999. Modeling in situ iron removal from ground water. Ground Water 37, no.6: 811-816.

Boochs P. W. and G. Barovic. 1981. Numerical model describing groundwater treatment by recharge of oxygenated water. Water Resources Research 17, no. 1: 49-56.

Braester C. and R. Martinell. 1988. The Vyredox and Nitredox methods of in situ treatment of groundwater. Water Science and Technology 20, no.3: 149-163.

Cornell R. M. and U. Schwertmann. 1996. The iron oxides. Structure, properties, reactions, occurence and uses. Weinheim: VCH.

Davies S. H. R. and J. J. Morgan. 1989. Manganese(II) oxidation kinetics on metal oxide surfaces. Journal of Colloids and Interface Science. 129: 63-77.

Diem D. and W. Stumm. 1984. Is dissolved $\mathrm{Mn}^{2+}$ being oxidized by $\mathrm{O}_{2}$ in absence of $\mathrm{Mn}$ bacteria or surface catalysts? Geochimica et Cosmochimica Acta 48: 1571-1573.

European Union. 1998. Richtlinie 98/83/EG des Rates.

Gibbs C. R. 1976. Characterization and application of Ferrozine iron reagent as a ferrous iron indicator. Analytical Chemistry 48, no.8, July: 1197-1201.

Groth P.. F. Bühring. R. Dannöhl, R. Liessfeld, R. Olthoff. and U. Rott. 1988. Unterirdische Enteisenung und Entmanganung - ein Statusbericht. Das Gas- und Wasserfach 129. no. $5: 321-339$.

Hallberg R. O. and R. Martinell. 1976. Vyredox - In situ purification of ground water. Ground 
Water 14, no.2: 88-93.

Heron G., C. Crouzet, A. C. M. Bourg, and T. H. Christensen. 1994. Speciation of Fe(II) and $\mathrm{Fe}(\mathrm{III})$ in contaminated aquifer sediments using chemical extraction techniques. Environmental Science and Technology 28: 1698-1705.

Jechlinger G., W. Kasper, F. Schöller, and F. Seidelberger. 1985. The removal of iron and manganese in groundwaters through aeration of the underground. Water Supply 3: 1925 .

Kleefeldt M. 1988. Hydrogeologische Aspekte der unterirdischen Enteisenung und Entmanganung von Grundwasser (UEE). bbr. Brunnenbau-Bau von Wasserwerken-Rohrleitungsbau 39: 92-98.

Kölle W. and B. H. Schneider. 1992. Die unterirdische Wasseraufbereitung. Neue DELIWAZeitschrift 6: 272-278.

Kostka J. E. and G. W. Luther III. 1994. Partitioning and speciation of solid phase iron in saltmarsh sediments. Geochimica et Cosmochimica Acta 58, no.7: 1701-1710.

Lovley D. R. 1987. Organic matter mineralization with the reduction of ferric iron: a review. Journal of Geomicrobiology 5: 375-399.

Lovley D. R. and E. J. P. Phillips. 1988. Novel mode of microbial energy metabolism: Organic carbon oxidation coupled to dissimilatory reduction of iron and manganese. Applied and Environmental Microbiology 54, no.6: 1472-1480.

Mahapatra D. M., G. Goswami, and J. D. Panda. 1996. A study of the occurrence of magnesium oxide in different phases of limestone. Cement and Concrete Research 26, no.7: $1057-1064$

Mengis H. 1984. Vyredox - Eine wirtschaftliche Methode zur Enteisenung und Entmanganung von Grundwasser. Gas-Wasser-Abwasser 9: 595-598.

Meyerhoff R. 1995. Anwendungsmöglichkeiten der in situ-Aufbereitung von eisen-und man- 
ganhaltigen Grundwässern. Aktuelle Entwicklungen in der Wasserversorgung aus Grund- und Oberflächenwässern: Stuttgart. 149-162.

Mouchet P. 1992. From conventional to biological removal of iron and manganese $\vdots$ in France. American Water Works Association, no.April: 158-167.

Murad E. and U. Wagner. 1994. The Mössbauer spectrum of illite. Clay Minerals 29: 1-10.

Murray J. W. 1974. The surface chemistry of hydrous manganese dioxide. Journal of Colloid and Interface Science 46, no.3: 357-371.

Olthoff R. 1986. Die Enteisenung und Entmanganung vom Grundwasser im Aquifer. Doctoral thesis, Unniversität Hannover.

Rey J.-P. and B.-A. Schindler. 1984. Essai de déferrisation d'eau de fond par la méthode Vyredox à La Neuveville (BE). Gas-Wasser-Abwasser 9: 599-603.

Rott U. and R. Meyerhoff. 1993. Wasseraufbereitung im Untergrund. Neue Deliwa Zeitschrift 3: $102-105$

Rundell B. D. and S. J. Randtke. 1987. In-situ groundwater treatment for iron and manganese: fundamental, practical and economic consideration. Annual Conference. American Water Works Association: Kansas City, MO. 513-533.

Schneider J. 1989. Profile Refinement on IBM-PC's. IUCr. International Workshop on the Rietveld Method: Petten. 71.

Schneider J. and R. E. Dinnebier. 1991. Gufi-Wyriet: An integrated PC powder pattern analysis package. Materials Science Forum 79-82: 277-282.

Schwertmann U. and R. Cornell. 1991. Iron oxides in the laboratory. Weinheim: VCH.

Seyfried C. F. and R. Olthoff. 1985. Underground removal of iron and manganese. Water Supply 3: 117-142.

Stookey L. L. 1970. Ferrozine- A new spectrophotometric reagent for iron. Analytical Chemistry 42, no.7: 779-81. 
Stumm W. and J. J. Morgan. 1996. Aquatic Chemistry. New York: John Wiley \& Sons, Inc.

USEPA. 2001. Office of Water. National secondary drinking water regulations. In Code of Federal Regulation, 612-614.

Van Beek C. G. E. M. 1985. Experience with underground water treatment in the Netherlands. Water Supply 3: 1-11.

Von Gunten U. and J. Zobrist. 1993. Biogeochemical changes in groundwater-infiltration systems: Column studies. Geochimica et Cosmochimica Acta 57: 3895-3906.

Weidler P. G. 1997. BET sample pretreatment of synthetic ferrihydrite and its influence on the determination of surface area and porosity. Journal of Porous Materials 4: 165 169.

Weidler P. G., J. Luster, J. Schneider, H. Sticher, and A. U. Gehring. 1998. The Rietveld method applied to the quantitative mineralogical and chemical analysis of ferralitic soil. European Journal of Soil Science 49, no.March: 95-105.

World Health Organization. 1996. Guidelines for drinking water quality. In Health criteria and other supporting information, Vol. 2, 248-253. Geneva: World Health Organization.

Zienkiewicz A. W. 1984. Removal of iron and manganese from ground water with Vyredox. Second International Conference on ground Water Quality Research: Stillwater, Oklahoma. 74-77. 


\section{Figure Caption}

Fig. 1. Schematic representation of the iron and manganese in situ removal plant of La Neuveville.

Fig. 2. Grain size distribution of the five sieved samples. Arrow depicts range of analyzed fractions.

Fig. 3. Specific concentrations in the fine fractions $(<0.5 \mathrm{~mm})$ of the sieved samples at different depths of the aquifer a) $\mathrm{Fe}_{\text {tot }}(5 \mathrm{M} \mathrm{HCl})$, b) ferric oxides (FeIII(TiEDTA)) and c) non reducible Fe from the difference $\mathrm{Fe}_{\mathrm{tot}}$ - FeIII(TiEDTA).

Fig. 4. Specific concentrations $\mathrm{Mn}_{\mathrm{tol}}(5 \mathrm{M} \mathrm{HCl})$ in the smallest grain size fractions $(<0.5 \mathrm{~mm})$ of the sieved samples at different depths of the aquifer.

Fig. 5. Correlation between ferric oxide concentrations in the sieved samples (FeIII(TiEDTA)) and their respective specific surface area, which was calculated from the radius of the particles and a density $\rho=2.6 \mathrm{~g} / \mathrm{cm}^{3}$.

Fig. 6. Diffractograms of sample P22. Upper curve: untreated sample, with peak positions of calcite ("c"). Lower curve: same sample after pretreatment with acetic acid, the peak positions of goethite are indicated as "gt" ("dol" = dolomite, "qz" = quartz). 

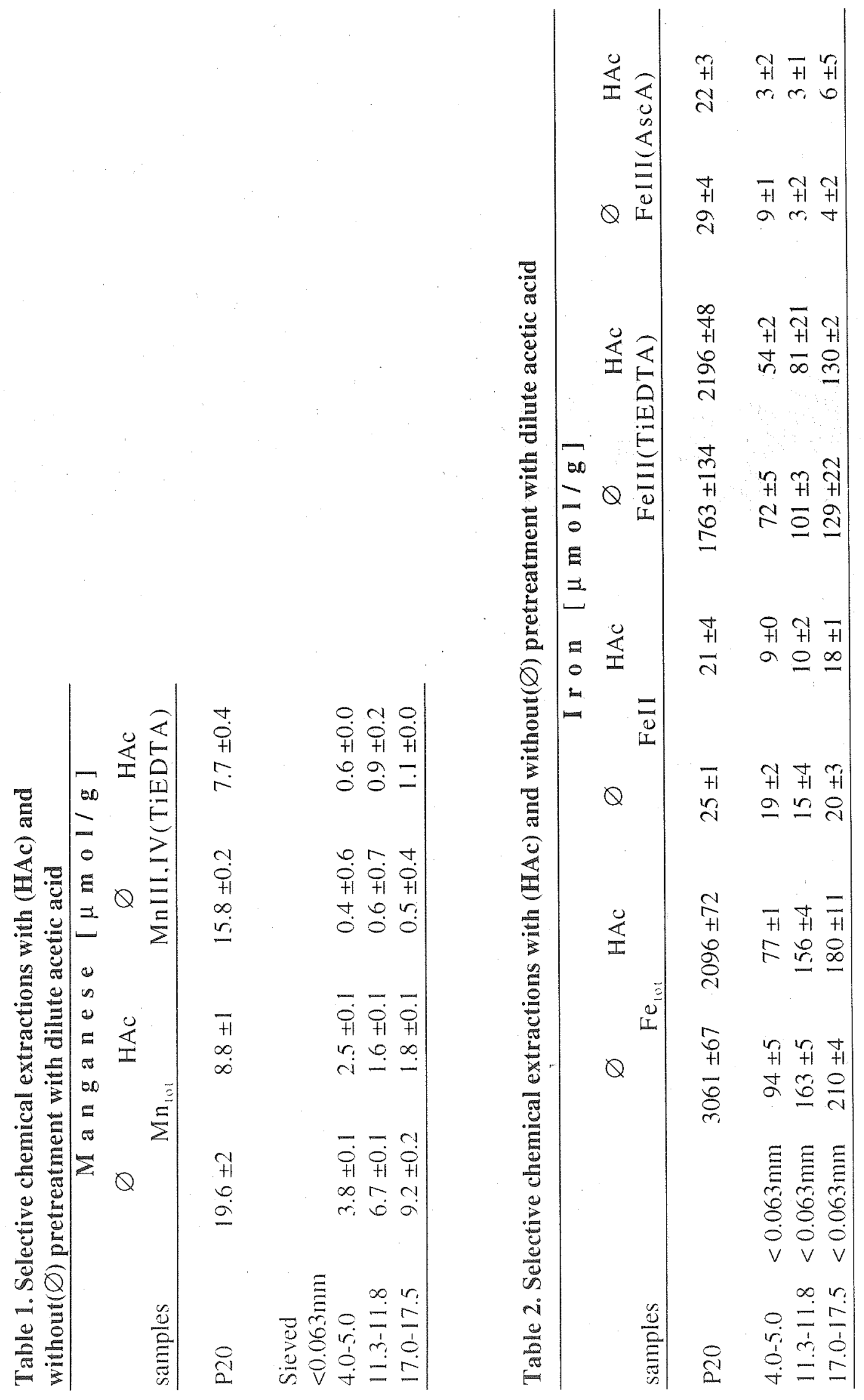


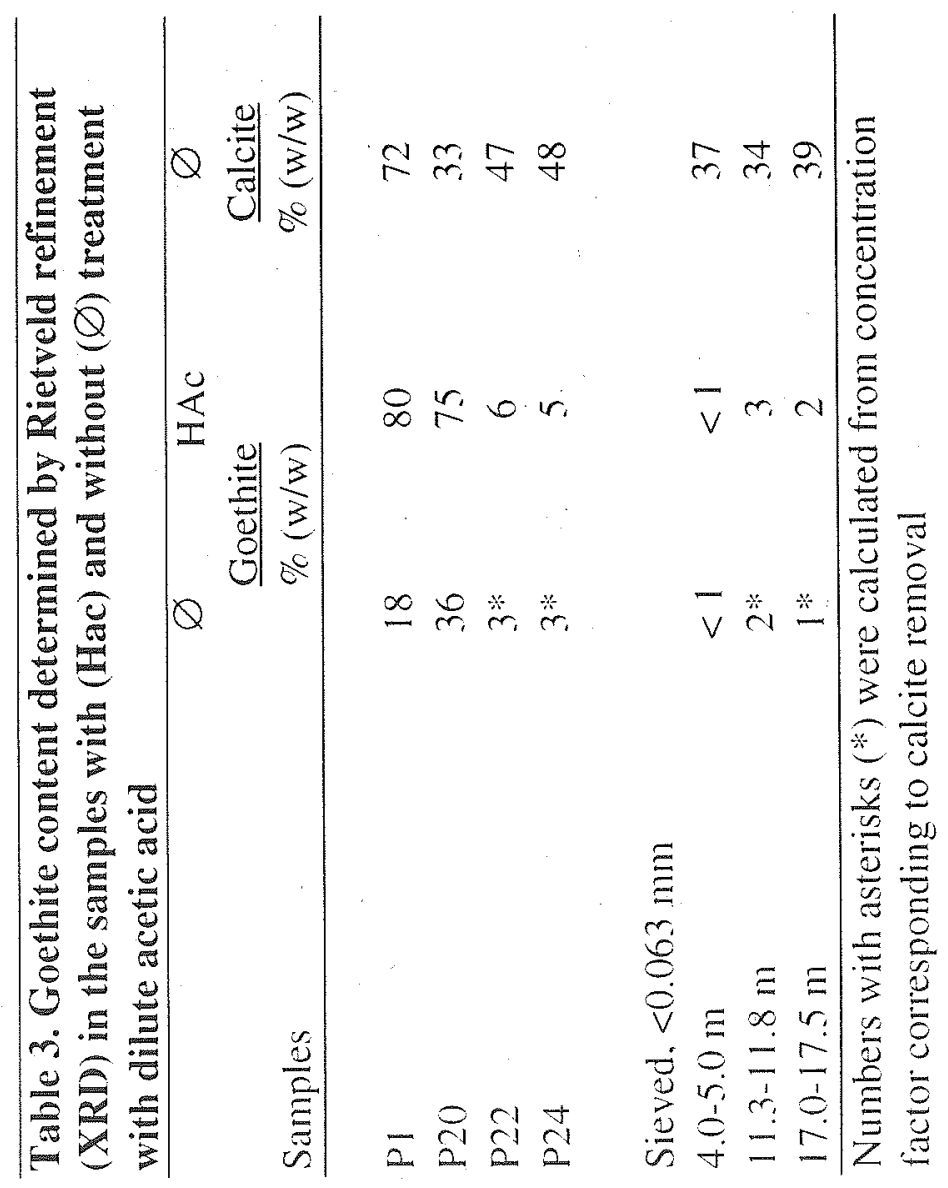




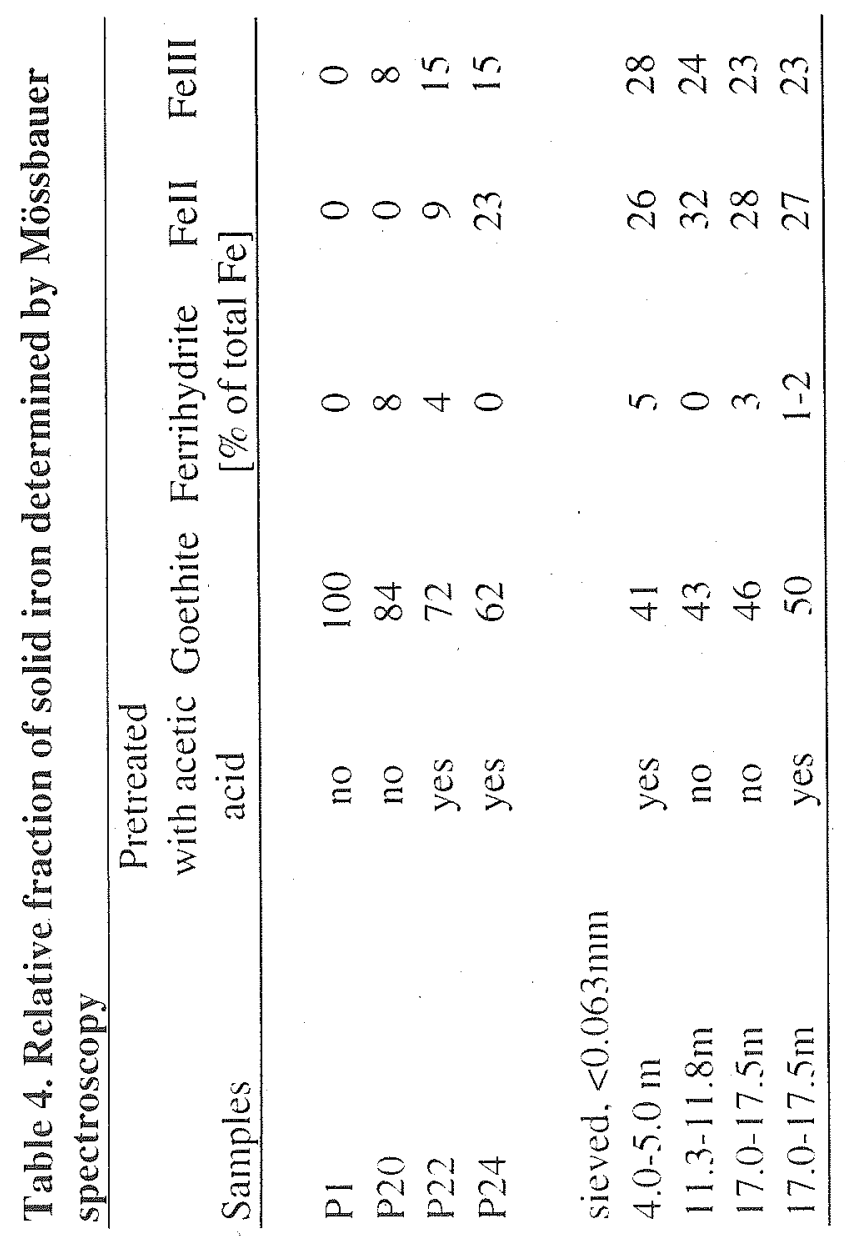




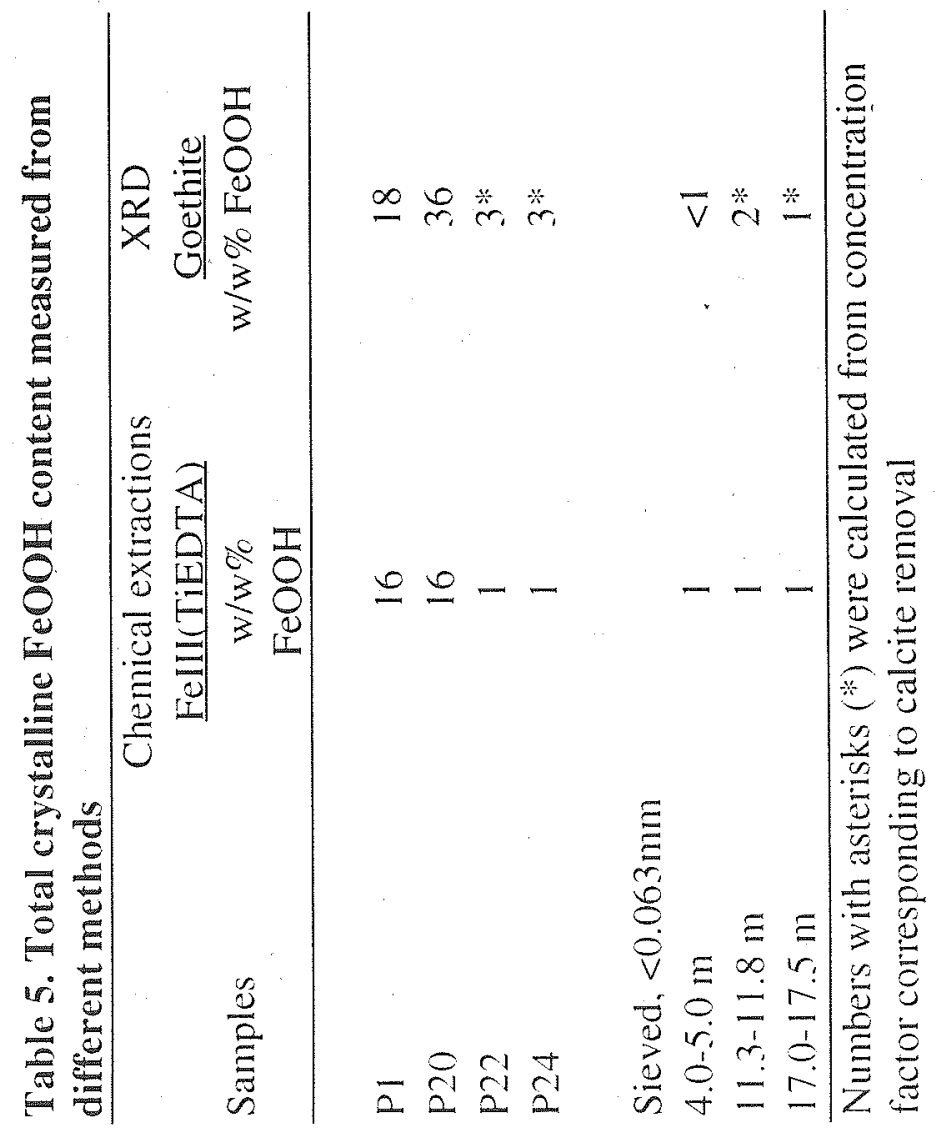




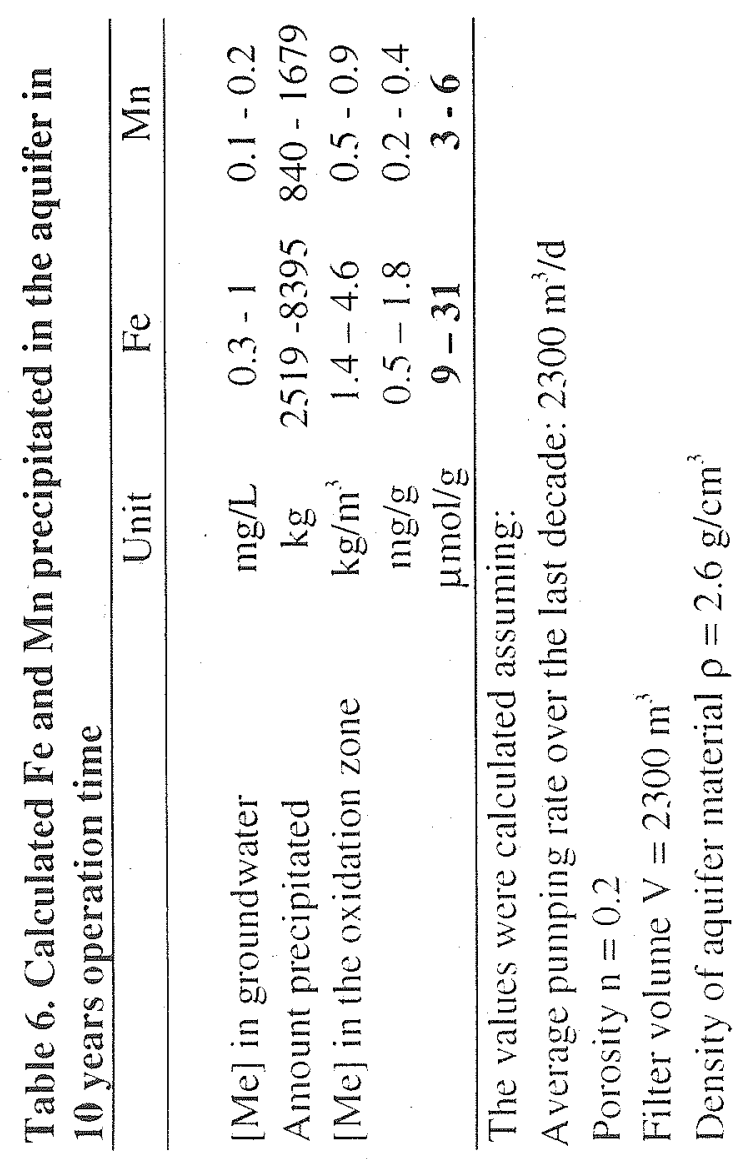




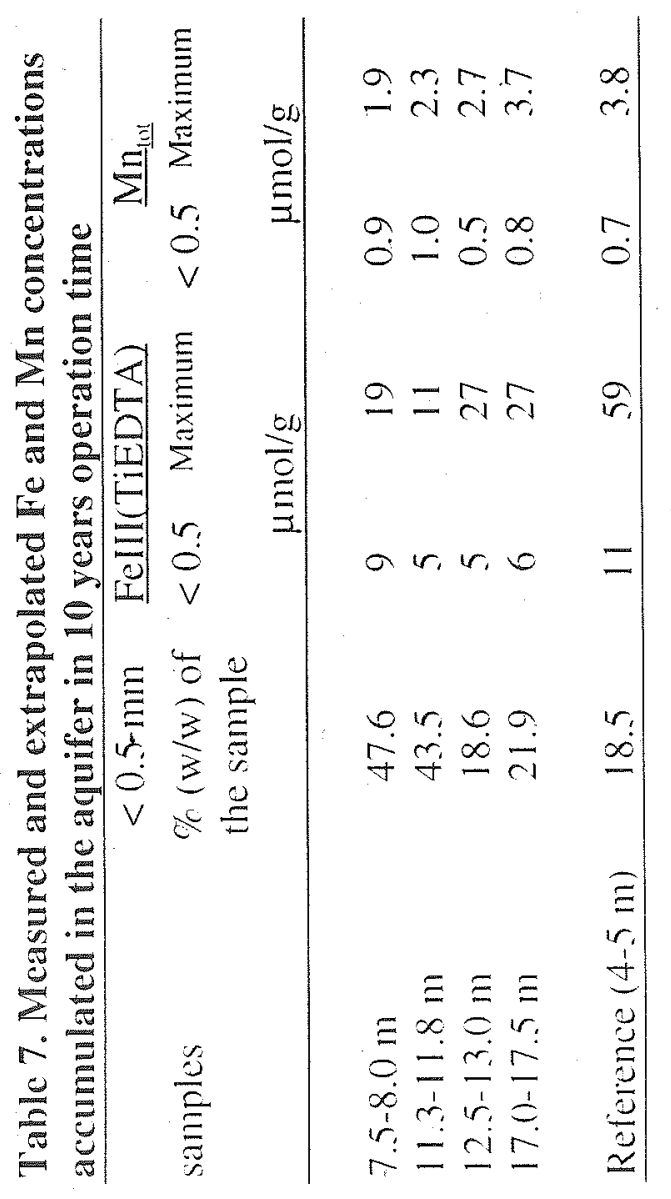


Fig. 1

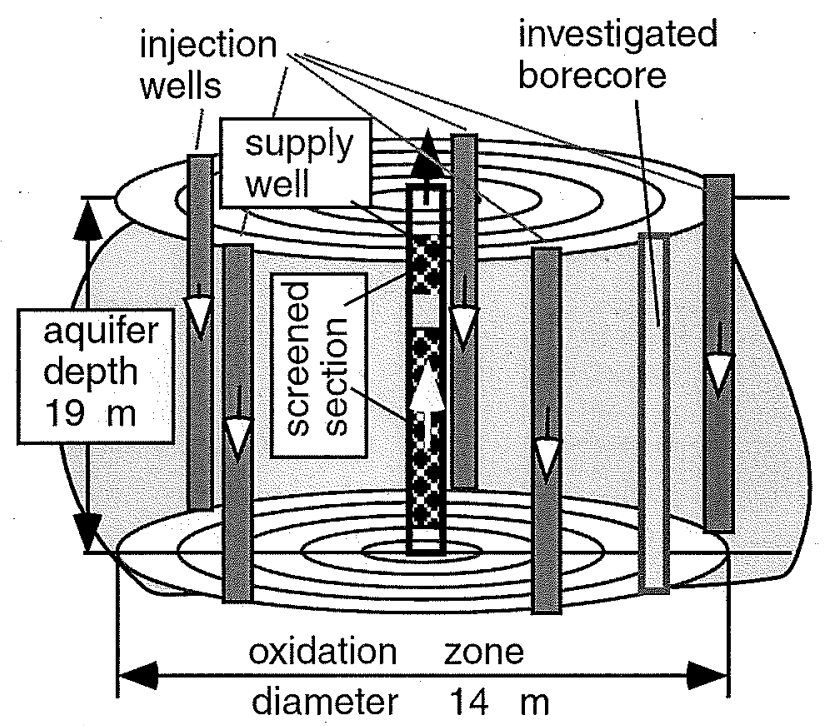


Fig. 2

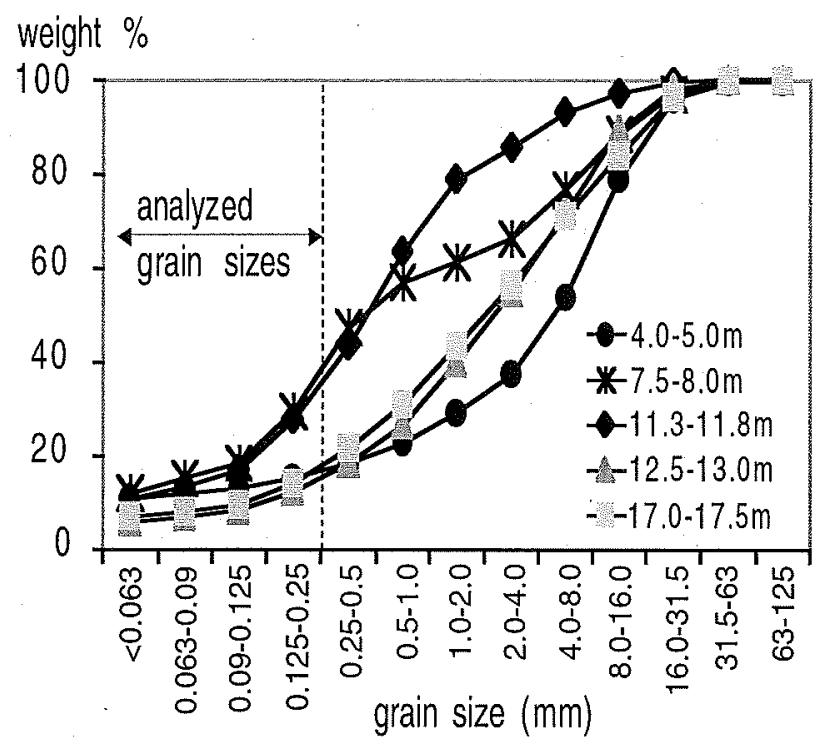


Fig. 3

S. Mettler et al., 2001

Concentration

$1 \mathrm{~mol} / \mathrm{g}$

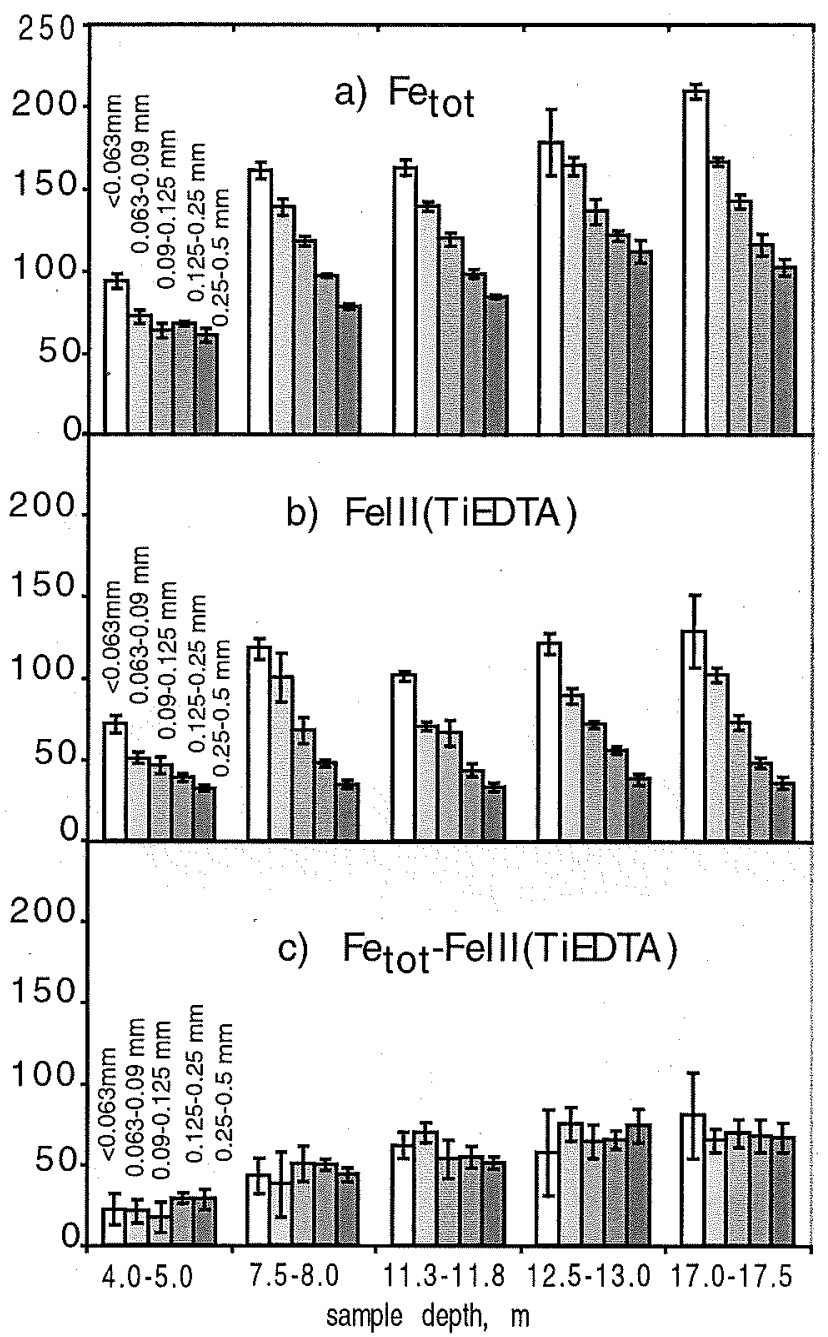


S. Mettler et al., 2001

Fig. 4

Concentration, $\mu \mathrm{mol} / \mathrm{g}$

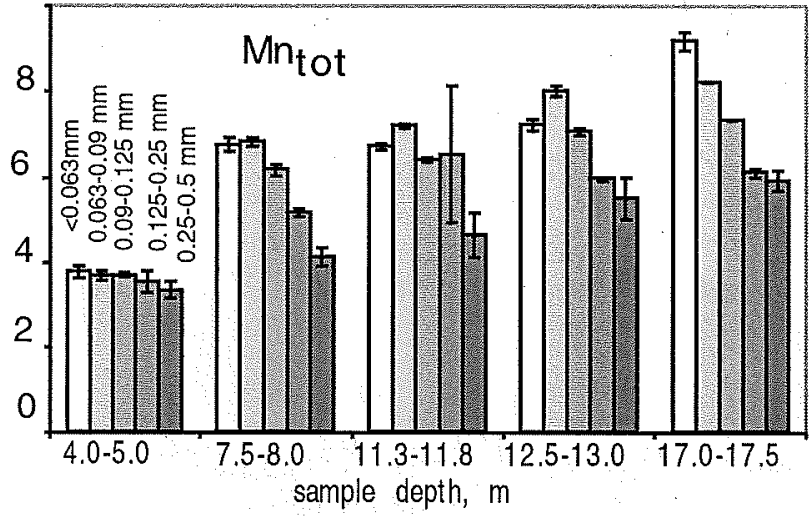


Fig. 5

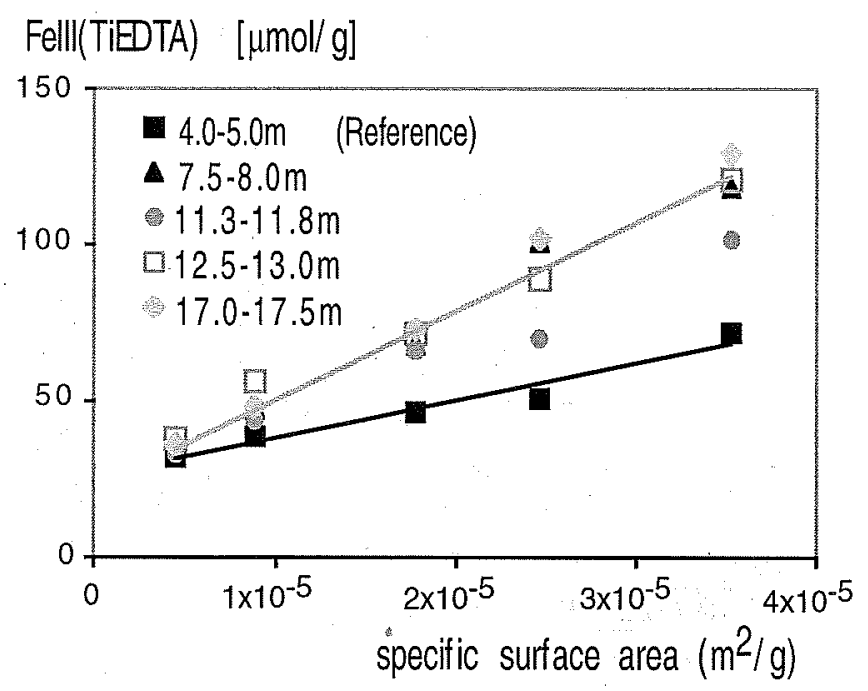


Fig. 6

S. Mettler et al., 2001

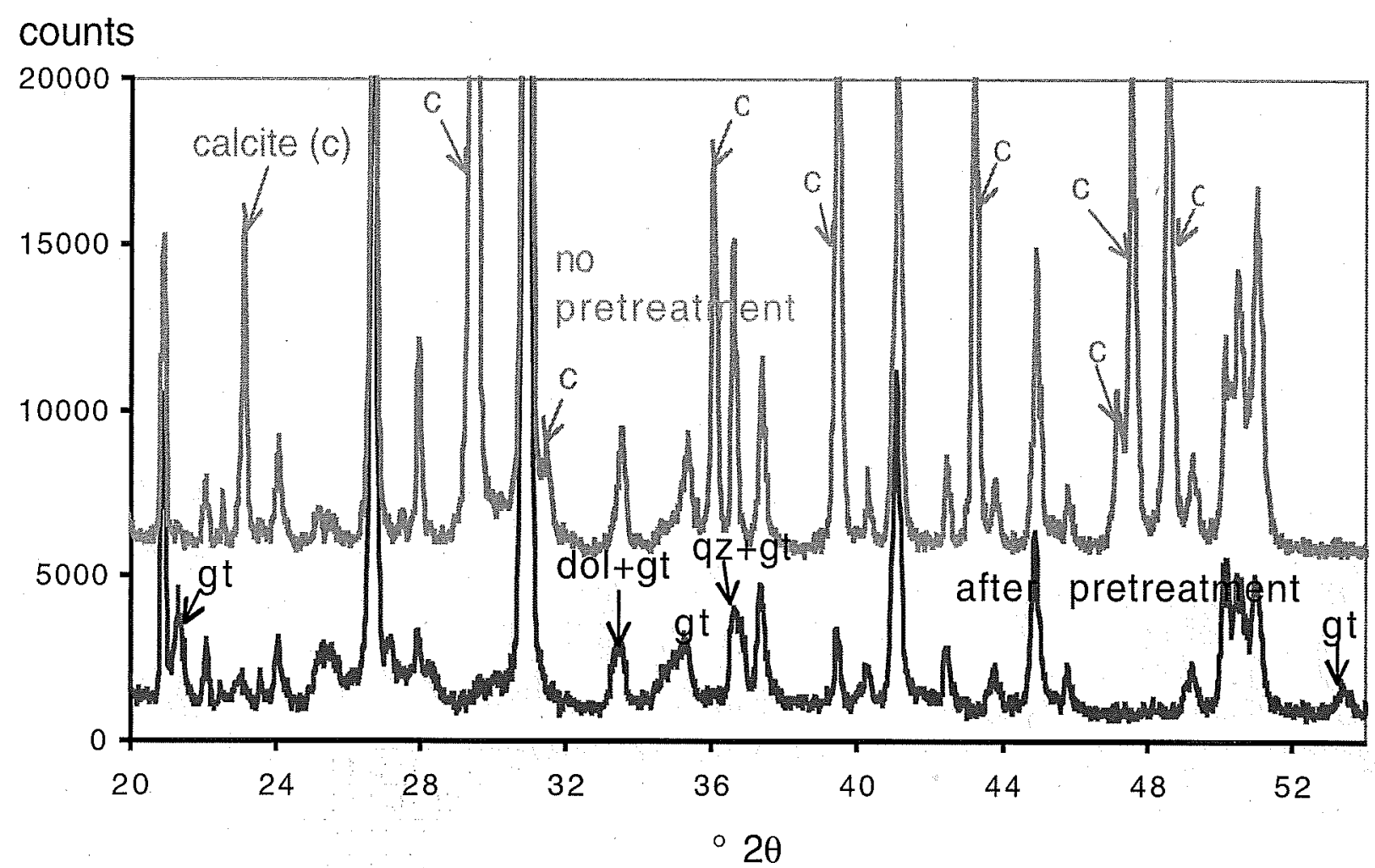

